\section{Cosmic Rays Near the South Magnetic Pole}

Admiral R. E. BYRD's book, "Antarctic Dis. covery" (Putnam and Co., Ltd.), which has just been published, contains a preliminary note on the cosmic ray records made by his expedition near the South Magnetic Pole. In an aeroplane flight from Little America (828 miles from the magnetic pole), a height of $12,000 \mathrm{ft}$. was reached and maintained for three hours while A. A. Zuhn made his observations. While the analysis of the records obtained during this flight, and also during regular ground-level observations, has not yet been completed, Admiral Byrd states that he has been informed by Zuhn that the intensity of radiation was fifteen times greater at $12,000 \mathrm{ft}$. than at ground-level in Little America, and eight times greater than that recorded in any observations made in the United States. It is to be regretted that it was necessary to replace the original argon of the ionisation chamber with carbon dioxide, owing to a leak which developed during thelong transport of the instrument. As, however, a radium capsule was available for standardisation, Admiral Byrd expresses the opinion that the validity of the records obtained will not be affected. He adds that a crucial test of this point is to be made before the records are formally published.

\section{Exhibition of Chinese Art at South Kensington}

THE exhibition of Chinese art at the Royal Academy, Burlington House, closed on March 7, when the number of visitors had reached the remarkable total of 422,048 . This number constitutes a record for all the recent winter exhibitions, with the exception of the exhibition of Italian art. It justifies the opinion expressed at the time the exhibition opened that the quality of Chinese art, when once certain conventions had been assimilated, was such in its general outlook and approach to reality as was likely to appeal to the susceptibilities of a British public. This was most strikingly manifested in the attention attracted by the transcendent qualities of the scroll landscape paintings; but it was also to be noted that the bronzes and other exhibits belonging to the early prehistoric period and the T'ang figures received little less detailed inspection, so far as conditions allowed. The popularity of the exhibition did not, indeed, conduce to a full appreciation of the subtler qualities of this great art, and it is, therefore, all the more gratifying to learn from the Directors of the British Museum and Victoria and Albert Museum that arrangements are being made for the exhibition at South Kensington at an early date of the Eumorfopoulos collection of Chinese art. This exhibition will include not only the purchased objects already assigned to South Kensington and the British Museum respectively, which will be brought together again for this purpose, but also that part of the collection of which the purchase is not yet complete, through the generous public spirit of the owner. If the public displays an interest in this collection in any way comparable to the enthusiasm shown at Burlington House, it should prove a strong incentive to early action in providing the much desired Museum of Asiatic Art, so greatly needed in London.
Palæolithic Implements of the Warren Hill Gravel

A selection from nearly 1,300 flint implements in the Sturge Bequest, from the gravel on Warren Hill, near Mildenhall, Suffolk, is on special exhibition at the British Museum, Bloomsbury, and will remain there for about three months. It will be found at the head of the main staircase, and is arranged in two desk-cases, one containing representatives of the main types and the other the specimens illustrated in the Sturge volume, with exceptional pieces showing the remarkable local patina and other special features. The exhibition is intended to show the sequence or association of implements in the same gravel, and to direct attention to the deposit, which is a geological puzzle. The long hill between Mildenhall and Icklingham lies at right angles to the River Lark near its south end, and was evidently formed before the valley was cut. The gravel seems to belong to an interrupted line of high-level deposits in a curve from Lakenheath to Snailwell, following the south. eastern boundary of the Fens. It is now generally held that this gravel bank is a glacial moraine; but there were thousands of implements included in it, and some in an unrolled condition enable a limiting date, if not a sequence, to be supplied on archæological grounds. The collection shows that, besides first-class hand-axes of St. Acheul character, there was also a striking proportion of flake-implements resembling in form those from High Lodge near the north end of the same ridge; and these are now thought to mark the third stage of the Clacton industry. Their horizon elsewhere is evident, but at Warren Hill it remains to determine the relation between the Clacton and St. Acheul series, and to identify the glaciation producing this apparently homogeneous gravel, which must have been derived from an area, once thickly inhabited, in the neighbour. hood. There is now a good opportunity to draw on the archæological material for a solution of the geological problem.

\section{Archæological Investigation in Cornwall}

Ar the close of the present month, the Cornish Excavation Committee will begin the excavation of Castle Dore, a hill-camp which lies between Lostwithiel and Fowey. The excavation will be carried out by Mr. C. A. Ralegh Radford, who was in charge of the recent excavations at Tintagel. The Castle Dore camp, being situated on the line of a trade route which linked up Ireland, Cornwall and the Continent in prehistoric times, holds out every prospect by its geographical position alone of yielding material of interest and importance for archæological studies; but in addition, recent research, notably by the late Prof. Loth, the Celtic scholar, and by the late Mr. Charles Henderson, whose untimely death was a great loss to Cornish archæology, indicates that Castle Dore may be a focusing point of traditions which seem to indicate a connexion here with the King Mark of Arthurian story, whose bride Iseult was brought from Ireland by Tristan. King Mark lived at "Lancien" which Prof. Loth suggested may be the original form of the name of Lantyan, the parish in which Castle Dore is situated, and he also 